\title{
Strategising management accounting: liberal origins and neoliberal trends
}

\begin{abstract}
Purpose:
Methodology

This paper draws on the concepts of biopolitics and neoliberal governmentality to provide a sociological analysis of the strategic turn in management accounting.

This conceptual and review paper addresses four interrelated questions. How can we revisit the early history of management accounting from a biopolitical angle? How has strategising been linked to the neoliberal evolution of capitalism? How has this neoliberal connection transformed management accounting into its new form of strategising? What are the implications of this transformation for future research and pedagogical practices in management accounting?
\end{abstract}

Findings

Originality

Research implications

Social implications

Management accounting is strategised in four interrelated directions: by absorbing the jurisdictional and veridictional roles of the market into the calculative practices of management accounting; by transforming management accounting's centripetal hierarchical order of calculations to a centrifugal order the neoliberal governmentality demanded; by re calculating the point of production as a site in which labour now takes the form of entrepreneurs of the self, performing not only material but also immaterial elements of managerial labour; and by rescoping management accounting to address issues the "fourth or the global age of security" brought, including the social and the environmental ones.

This paper makes a theoretical contribution to management accounting's contemporary developments by demonstrating how it moves into biopolitical circulation.

The research expands the existing frames of reference for exploring contemporary calculative practices in neoliberal governmentality.

Strategic turn in management accounting implicates in issues of security, governance, and ethics and offers 'new opportunities' for expanding management accounting's relevance beyond economic enterprises to various civil society and political constituencies.

Keywords: neoliberalisation, management accounting, strategy, strategising.

\section{Introduction}

Although management accounting's early history has been well theorised and explained in the context of industrial capitalism (see Johnson and Kaplan 1987; Hoskin and Macve 1994; Hopper 
and Armstrong 1991; Hoskin and Macve 1986, 1988; Loft 1995), yet its recent history in the context of neoliberalism has not received noteworthy attention. Although accounting researchers have identified this neoliberal trend and explored some interesting issues (e.g., Andrew and Cahill 2017; Andrew and Cortese 2013; Baud and Chiapello 2017; Chiapello 2017; Cooper et al. 2010), apart from Alawattage and Wickramasinghe (2019) publication, there has been no comprehensive review of how the processes of strategising link to neoliberalism. Certain studies have nevertheless considered strategy as their analytical focus. For example, some explored how accounting actors become involved with and use accounting devices in strategy making (Roslender 1995; Roslender and Hart 2003; Whittle and Mueller 2010), how the use of accounting in strategy making can be seen as an everyday practice in response to environmental dynamics (Begkos et al. 2019; Chia and Holt 2006), and how strategising takes place as a practical coping mechanism (Begkos et al. 2019). However, these studies paid little attention to how strategising can be situated within the evolutionary dynamics of neoliberal capitalism. Although they explicate pluralist settings within which strategising occurs, the neoliberal logic of competitiveness has been inadvertently neglected. Despite some critical accounting researchers exploring the neoliberal impulses in accounting, management accounting's strategic turn was not their focus. Nevertheless, the theoretical directions they set are useful (Cooper 2015; Cooper et al. 2010; Miller and Rose 2008; Alawattage et al. 2019).

This paper uses Foucault's ideas of biopolitics and neoliberal governmentality to address four interrelated questions:

1. How can we revisit the early history of management accounting from a biopolitical angle?

2. How has strategising been linked to the neoliberal evolution of capitalism?

3. How has this neoliberal connection transformed management accounting into its new form of strategising?

4. What are the implications of this transformation for future research and pedagogical practices in management accounting?

The paper is structured as follows. Section 2 outlines our theoretical perspective. Section 3 articulates how strategising can be seen from the old spirit of capitalism, doing so around three interrelated themes: historical contours, faith of strategy, and state of management accounting. Section 4 uses the same themes to explore and compare how strategising is involved in neoliberal governmentality. Finally, Section 5 summarises and concludes the paper.

\section{Theoretical framing}

Attempts at theorising management accounting history have taken three competing perspectives: neo classical economics, Marxist, and post $\sim$ Marxist (for a detailed account, see Loft 1995; Roslender 1996). Initially, Johnson and Kaplan's (1987) transaction cost theorisation provoked a stream of alternative, critical theorisations. For example, Hopper and Armstrong's (1991) Marxist labour process theorisation explored the emergence of management accounting within the context of class struggle at the point of production. They argued that the initial institutional and political conditions within which management accounting emerged were created at the early stage of industrial capitalism by the capitalistic necessity of subsuming and controlling labour through deskilling. Later stages required the controlling of the managerial labour process using hierarchical accountability structures that are geared to ensure a maximum or sufficient return on investment. These developments echo a structural interpretation of management accounting as a political technology that reproduces capitalist relations in and of production. As Cooper and Hopper (2006, 209) argue, management accounting history needs a Marxist perspective given that management accounting cannot be "an inevitable outcome of market forces and technological change but is implicated in, and reflects, political, social and economic struggle, the outcome of which are contingent". In the eighteenth and nineteenth centuries, this struggle materialised in factory -based capitalist labour processes, where labour power was subordinated to capital through Taylorite deskilling and Fordist assembly line (Braverman 1998 [1974]), while costing and budgeting played a critical role in profit planning and controls (Hopper and Armstrong 1991). The management accounting literature is rich in this structural interpretation (Bryer 2000b, 2000a; Hopper and Armstrong 1991; Hopper and Powell 1985; Hopper et al. 1987; Neimark and Tinker 1986). 
In contrast, reading Foucault, post - Marxists (e.g., Hoskin and Macve 1994; Hoskin and Macve 1986,1988 ) focused on disciplinary apparatuses and genealogical events to understand how management accounting emerged. They argued that management accounting technologies evolved to discipline modern subjects as "describable and analysable objects" (Foucault 1979, 190). They also understood management accounting history in terms of genealogies that trace a transformation of sovereignty into governmentality through disciplinary institutions, techniques, and principles (see Alawattage and Wickramasinghe 2019). In this sense, then, management accounting is a set of disciplinary techniques and practices that make the subjects calculable and, in turn, governable (e.g., Hopper and Macintosh 1993; Hoskin and Macve 1994; Hoskin and Macve 1986, 1988; Miller 2001; Miller and O'Leary 1987, 1993, 1994). Recent extensions to this Foucauldian understanding explored how a new set of techniques and practices emerged in the neoliberal times to recalculate these subjects as "entrepreneurial selves" (Cooper 2015; Cooper et al. 2010; Miller and Rose 2008; Alawattage et al. 2019).

These recent post $\sim$ structural theorisations, especially their conceptualisations of neoliberal governmentality and biopolitics, help us articulate an analytical framework for capturing how a new set of neoliberal biopolitics necessitates strategising management accounting. Neoliberalism is the global scale intellectual and political commitment to extend the market logic of competitiveness to every realm of social life (Harvey 2005; Peck and Tickell 2002; Chomsky 1999). It replaced the post $\sim$ war Keynesian state led governance with a new form of political ideology that sees human wellbeing can be better advanced by promoting the entrepreneurial spirit among individual subjects through market -based governance (Brown 2006, 2015; Harvey 2005). Strategising management accounting is an epistemic transformation in management accounting to enable the neoliberal reproduction of the entrepreneurial self (Alawattage and Wickramasinghe 2019; Cooper 2015; Munro 2012). In the name of strategising, management accounting is now evolving into a myriad of calculative/rationalisation techniques and practices that "conduct the conduct" (i.e. governance when conceptualised through governmentality) through putting the lives into circulation and reproducing them as entrepreneurial selves. Management accounting now helps organise populations as collectives of innovative, productive, self $\sim$ disciplined, and strategising subjects in a realm of life where everything is seen as a market or market like competition (cf., Moisander et al. 2018).

Marxist and post - Marxist theorisations share the notions of capital and capitalism. In both historical and contemporary senses, accounting is an ever evolving set of calculative techniques and practices that enable the reproduction of capital within and outwith various organisational entities. Whether one sees this within the agency relationships between the shareholders and their stewards, as in the case of neo classical economic theorisations, or within the duality between labour and capital, as in the case of Marxist structuralism, or even as a specific set of disciplinary institutions, principles, and techniques through which modernity beget capitalism into existence, as in the case of Foucauldian analyses, the notion of capital or capitalism occupies a central place in such theorisations. For critical accounting scholars, capital is not only an abstract category of social class or economic totality but also a day - to day calculative reality manifested by various accounting techniques. It is an overarching socio political phenomenon with which every other socio political and economic decision needs to be associated. Hence, the manner in which capitalism evolves provides the historical and political conditions upon which one can trace how management accounting evolves. Accordingly, our fundamental premise is that strategising management accounting needs to be understood in the broader political economic conditions, which we now generally understand as neoliberal capitalism and its disciplinary/control apparatuses, which we call neoliberal governmentality.

Neoliberal governmentality needs to be understood vis à $\sim$ vis liberal governmentality. To this end, we use the following three distinct but interrelated comparative dimensions.

a) Historical contours capture three interrelated macro political conditions: the liberational ideology (the dominant set of political ideologies towards which the socio political, economic, and institutional transformations are directed); the institutionalisation of the 
socialised capital (i.e. firm capital and share capital); and the (re)configuration of the point of production.

b) The faith of strategy. How the notions of strategy are conceived and operationalised, especially the calculative rationalisations with which social entities are governed.

c) State of management accounting: the form management accounting takes to enable and enact the conditions mentioned in points (a) and (b) above.

Table 1 summarises our comparative understanding of liberal and neoliberal governmentality and provides a roadmap of the paper.

Table 1: Management accounting liberal origins and neoliberal trends

\begin{tabular}{|c|c|c|}
\hline Themes of inquiry & $\begin{array}{l}\text { Liberal governmentality } \\
\text { (i.e. the historical political conditions } \\
\text { upon which conventional form of } \\
\text { management accounting evolved) }\end{array}$ & $\begin{array}{l}\text { Neoliberal governmentality } \\
\text { (i.e. the historical political conditions } \\
\text { upon which strategising management } \\
\text { accounting takes place) }\end{array}$ \\
\hline \multicolumn{3}{|l|}{ Historical contours } \\
\hline $\begin{array}{l}\text { 1. Political -economic } \\
\text { and ideological } \\
\text { context }\end{array}$ & $\begin{array}{l}\text { Liberal political economy: Liberating the } \\
\text { subject from the state's sovereign power } \\
\text { through modern governmentality } \\
\text { apparatuses (e.g. political and corporate } \\
\text { bureaucracies, civil and professional } \\
\text { services, and elected parliament), free } \\
\text { labour, and free markets; accumulating } \\
\text { private capital becomes normativity } \\
\text { activity of economic being. }\end{array}$ & $\begin{array}{l}\text { Neoliberal political economy: Liberating } \\
\text { the economy from the polity (i.e. } \\
\text { liberating markets from the } \\
\text { dysfunctionalities of state intervention } \\
\text { and bureaucratic governance so that } \\
\text { individual subjects can marketise their } \\
\text { self and their life to gain entrepreneurial } \\
\text { opportunities whereby they accumulate } \\
\text { private capital). }\end{array}$ \\
\hline \multirow[t]{2}{*}{ 2. Institutional context } & $\begin{array}{l}\text { Constructing the firm and the capital } \\
\text { market as the institutional infrastructure } \\
\text { within which capital came into being. }\end{array}$ & $\begin{array}{l}\text { Reconstructing and deconstructing the } \\
\text { firm and the hierarchy into heterarchies, } \\
\text { networks, and platforms to enable the } \\
\text { circulation of capital and of life itself. }\end{array}$ \\
\hline & $\begin{array}{l}\text { Capital predominantly exists as a firm } \\
\text { centric phenomenon. }\end{array}$ & $\begin{array}{l}\text { Capital predominantly exists as a } \\
\text { market } \sim \text { centric phenomenon. }\end{array}$ \\
\hline $\begin{array}{l}\text { 3. The point of } \\
\text { production }\end{array}$ & $\begin{array}{l}\text { Factory as the prominent point of creating } \\
\text { surplus value; the owning and managing } \\
\text { of such capital provides the dominating } \\
\text { basis of becoming rich and powerful. } \\
\text { Surplus value ensured through the } \\
\text { centripetal confinement of the body to be } \\
\text { disciplined within the disciplinary cells of } \\
\text { time and space. Hence, the anatomico } \\
\text { politics of the body play a prominent role } \\
\text { in creating surplus value. }\end{array}$ & $\begin{array}{l}\text { Markets, networks, and platforms are } \\
\text { the prominent points of creating } \\
\text { surplus value; efficacy with which } \\
\text { one's body and life (together with the } \\
\text { disciplinary spaces in which they } \\
\text { operate) are put into centrifugal } \\
\text { circulation across market networks } \\
\text { and platforms is the dominating basis } \\
\text { of becoming rich and powerful. } \\
\text { Thus, biopolitical circulation is the } \\
\text { dominating form of creating surplus } \\
\text { value. }\end{array}$ \\
\hline Faith of strategy & $\begin{array}{l}\text { Strategy discourses often operated in the } \\
\text { rhetoric of industrial/business policy; } \\
\text { strategy resides within the domain of } \\
\text { industrial/macro economics, driven } \\
\text { towards establishing the macro economic } \\
\text { and industrial infrastructure for } \\
\text { enhancing allocative and productive } \\
\text { efficiency (i.e. 'perfecting' the } \\
\text { market/industry). Policy discourses } \\
\text { dominated by the political state and its } \\
\text { administrative apparatuses, such as the } \\
\text { Central Bank and the ministries. }\end{array}$ & $\begin{array}{l}\text { Discourses emerged to relocate the } \\
\text { strategy in the realm of corporate } \\
\text { top management, where the strategy } \\
\text { is perceived as being the leadership } \\
\text { that sets long term corporate goals } \\
\text { and policies to drive corporations } \\
\text { towards global excellence in their } \\
\text { competitive performance. Epistemic } \\
\text { infrastructure evolved to support this } \\
\text { in terms of consultocracy and 'think } \\
\text { tanking'. Strategising encompasses all } \\
\text { possible modes of calculative } \\
\text { rationalisations that enact and enable } \\
\text { competition in every realm of social } \\
\text { and economic life. }\end{array}$ \\
\hline $\begin{array}{l}\text { State of management } \\
\text { accounting }\end{array}$ & $\begin{array}{l}\text { Centripetal with disciplinary techniques } \\
\text { and practices, aiming at efficiency through } \\
\text { confinement and regulation in the } \\
\text { disciplinary cells of time and space. }\end{array}$ & $\begin{array}{l}\text { Centrifugal with post } \text { disciplinary } \\
\text { techniques and practices, aiming at } \\
\text { creating value through circulation } \\
\text { across markets, networks, and platforms. }\end{array}$ \\
\hline
\end{tabular}

The neoliberal transformation summarised above is simultaneously micro organisational and macro political. As some social theorists argue (see Chomsky 1999; Foucault 2008; Harvey 2005), neoliberalism entails macro political transformations of political ideology and state reforms 
initiated by Raegan and Thatcher governments. So, certain political impetus for change emanated from global politics. On the micro level, such politico ideological transformations were nevertheless made possible through techno managerial innovations in specific practices within markets and hierarchies. In a Marxist sense, the labour process, or the relations in production, constitute the techno managerial relations people enter into when creating surplus value (see, Burawoy 1979; Marx 1990 [1867]), while the markets constitute relations of production and host the valorisation and the appropriation of surplus value. This liberal construction of the firm/factory and the market thus forms two distinct but interrelated elements of capitalist accumulation. In its modernist calculative sense, capital came into being within this institutional construction of the firm as the unit of capital wherein surplus value is created, or in other words is defined and calculated, with the market being the site in which firms compete to valorise and appropriate the surplus value.

In neoliberal capitalism, creation and valorisation provide the market's competitive parameters yet have also been brought into the point of production. The point of production, where conventionally labour power was subsumed as material labour, is now reconfigured as a site of competition and circulation, where labour is now transformed into "entrepreneurs of the self" (Cooper 2015) to circulate their lives in competition. Management accounting thus acts upon neoliberal governmentality and constructs "entrepreneurs of the self", doing so by displacing the labouring self and relocating it within a stream of proxies that brings the markets, hierarchies, and networks together at the point of production. This process blurs and disguises the antagonism between labour and capital - the fundamental antagonism of capitalism. Techno managerial and epistemic reconstruction of markets within hierarchies, networks, and platforms now account intra organisational actions as competitive market performance and, hence, 'strategic actions' (Alawattage and Wickramasinghe 2019).

In enacting neoliberal governmentality, for intensifying accumulation through circulation, bodies need releasing from the old disciplinary cells of labour and relocating in sites of circulation such as markets, networks, and platforms, where labour can assume its new identity of being entrepreneurs of the self who put their lives into circulation. For this to happen, old disciplinary cells need reconfiguring as competitive spaces. This is what strategising management accounting accomplishes, and it does so through various apparatuses of strategy that reinvent the point of production as a point of competition in which labour needs to reinvent itself as entrepreneurship. Digitalised and virtualised performance measurements now enable the worker to identify and appreciate him/herself as competing at work (vis $\mathfrak{a}$-vis working), not only with other workers against whom their performances are continuously compared and benchmarked but also with him/herself (e.g. managerial slogans of 'beat your yesterday').

To this end, management accounting now needs to enact and enable markets, networks, platforms (or any other form of circulatory relations of accumulation and exploitation) at the point of production. This essentially involves reproducing the relations in and of production as what they are indeed not: production as exchange and competition, labour as capital/entrepreneurship, and the market as justice. This is done by mirroring calculated images of markets on to the point of production as averages, benchmarks, demographics, big data analytics, and so on. This mirroring of the market in effect constitutes a heterotopia, as Foucault (1986) would call it - a mirror, based upon which one would place himself/herself where s/he is not (see Section 4 below). Thus, the market is enacted as a calculative reality at the point of production when accounting constructs the markets as a mirror upon which organisational actors calculate, locate, and see themselves as comparative and competitive figures. Such images then feed into governance practices as they enable the market's jurisdictional and veridictional roles, making the market the ultimate site of jurisdiction and veridiction. That is the neoliberal logic of governance whereby the market becomes the 'conductor of the conduct' through veridiction and jurisdiction. In this neoliberal logic of governance, the market is calculated and reflected as just and veridictional. So, when there are possibilities for calculating and reproducing the markets through techno managerial and epistemic innovations, the market logic penetrates the polity and society. These realms have hitherto been considered transcendental to markets but are now being subjugated to the calculative logics of the markets that accounting now brings into life through its sophisticated calculations. Strategising 
management accounting must thus be seen as an enabling element of neoliberal governmentality whereby the market becomes the conductor of the conduct (cf., Moisander et al. 2018).

\section{Liberal origins}

\subsection{Historical contours: biopolitics and the anatomico politics}

The conventional form of management accounting's historical and political context is premised on the manner in which liberal governmentality transformed the sovereign power into a liberal form during the Enlightenment, modernity, and industrial capitalism. If we look at this as the "conduct of the conduct", liberal governmentality connotes an "art of exercising power in the form of economy" (Foucault 2003, 233) where there was a continuity between morality, economy, and politics in upward and downward directions through the use of a set of disciplinary principles, institutions, and technologies. To appreciate the disciplinary underpinnings of management accounting, two key pillars of neoliberal governmentality need clarifying.

First is the historical construction of population and economy as a datum - a calculable biopolitical entity for political intervention. This involves so introducing the economy into political practices that governing means governing "things". Accordingly, governmentality involves "conducting the conduct" of the

men [sic] in their relations, their links, their imbrications with those things that are wealth, resources, means of subsistence, the territory with its specific qualities, climate, irrigation, fertility, and so on; men in their relation to those other things that are customs, habits, ways of acting and thinking, and so on; and finally men in their relation to those still other things that might be accidents and misfortunes such as famine, epidemics, death and so on (Foucault 2003, 235).

Economy and population are thus conceived as an aggregative 'bio', pathologies of which (e.g. poverty, ill health, illiteracy, crime rates, unemployment, lack of economic growth, lack of competitiveness etc. etc.) have hence become the 'biopolitical' parameters through which economy and population become a datum and a field of political intervention (see Miller and Rose 1990b). Political intervention here concerns the connection and continuity between the population's biopolitics and the human body's anatomico politics , which simultaneously locates the individual body in two corresponding spectra of governance: as a statistical element of the "political rationalities" (Miller and Rose 1990a); and as individual anatomy that needs disciplining within the specific productive cells to which it is variently associated. The body's connection to the aggregate is centrifugal and connotes biopolitics; its connection to the productive cell is centripetal and connotes anatomico politics (Foucault 2008; Nadesan 2008). Governmentality thus simultaneously operates two forms of power/politics: biopower/biopolitics, which centrifugally relates the disciplined body to the aggregate; and disciplinary power/anatomico politics, which centripetally confines the body in the productive cell at the point of production.

Secondly, disciplinary principles and techniques associated with modern disciplines such as medicine, psychiatry, psychology, engineering, economics, and accounting formed a disciplinary ensemble constituting a new set of disciplinary institutions. This set included factories, offices, hospitals, and schools, which for Foucault (1979) all resemble prisons, perhaps understandably so given that they constitute productive cells within which the human body is confined and disciplined through various knowledge power connections that subjectivate and objectivate the body - for example, as patients, doctors, students, teachers, employees, labourers, and managers (see Foucault 1979). The factory, the signatory disciplinary institution of capitalism, indeed objectivated and subjectivated the body as labour deskilled and subsumed for capital accumulation. The corporation and the capital market, together with the factory, provided the institutional context within which liberal forms of management accounting evolved, while other elements of the disciplinary ensemble such as commercial law, double -entry bookkeeping, and industrial engineering provided the epistemic context. They encapsulated a liberational ideology of the market being a "natural system of liberty" in which, as Adam Smith (Smith 2012 [1776]) claimed, 
[e]very man [sic], as long as he does not violate the laws of justice, is left perfectly free to pursue his own interest his own way, and to bring both his industry and capital into competition with those of any other man, or order of men.

"The art of exercising power in the form of economy" (Foucault 2003, 233) involved two interdependent historical processes: 'socialisation of private capital' at the biopolitical end and 'capitalisation of production' at the anatomico political end. These were the means through which the 'sovereignty of feudal aristocracy' was transformed into the 'governmentality of capitalist bureaucracy'. The 'socialisation of private capital' involved the invention of corporations and shareholdership so that ownership of society's dominating factor of production was 'freed' from the feudal rules of heredity, kinship, and kingship. With this, capital came into existence, divisible into its ultimate unit - a 'share', in its most socialisable form, socialising being trading in a market specifically designed for it - the capital market. Hence, the power of appropriating the surplus value that the social systems create became 'free' from its feudal conditions of heredity, kingship, and kinship and instead was made available to the capital market's highest bidders. Corporations, capital markets, and capital itself thus manifested a form of liberation at its historical inception compared with the degree of freedom of ownership that prevailed in the feudal aristocracy.

By being incorporated into the corporation, as an incorporated body and a legal personality, capital is a transcendental form of existence - an organic, self realising, and competing entity capable of coordinating, controlling, governing, facilitating, empowering, and developing as well as disturbing, destructing, enslaving, and exploiting the lives of all other human and non human beings. By forming itself into corporations, capital has become the most dominating institutional apparatus of governmentality - the fundamental entity in which "the art of exercising power in the form of economy" is practised. By forming into corporations, capital separates itself from its ownership and management, which are then expected to invest in and work for the corporation, making the corporation teleological. While certain socio political and economic benefits would accrue to the other social actors associated with it discriminately, capital exists for its own expansion predominantly in the form of incorporated bodies and accounting entities.

\subsection{Faith of strategy}

The term strategy connotes diverse meanings stemming from a range of disciplines, including industrial economics (see Porter 1981; Williamson 1975, 1988, 1991), business policy (see Bower 1982), and economic history (Chandler 1963), with distinct theoretical standings such as transactions cost economics (Chandler 1963; Williamson 1975, 1988, 1991), game theory (Heifetz 2012; Niou and Ordeshook 2015), and resource based theory (McKiernan 1997). This practical and theoretical trajectory demonstrated that strategy determines firms' expansion and diversification in terms of competitive goals and actions that synchronise the companies' conduct with their external environmental demands. This aligns with Alfred Chandler's strategy and structure thesis, which enormously influenced the early development of strategy discourses by defining strategy as "the determination of the long-term goals and objectives of an enterprise, and the adoption of courses of action and the allocation of resources necessary for carrying out these goals" (Chandler 1963, 13). After Chandler's thesis, however, the notion of strategy evolved, primarily into two approaches: the neo classical one from the 1950s to the late1970s; and the neo liberal one of the 1980s and beyond (Alawattage and Wickramasinghe 2019). We address the neo classical version in this section, leaving the neoliberal version to the section 4.2.

Mass production and mass marketing were the defining characteristics of industrial capitalism's pre neoliberal regime. US and European companies enjoyed a high degree of monopoly power in undifferentiated large domestic markets because of protectionist political regimes, but the market demand was not generally deemed a strategic challenge. Instead, what were considered critical constraints were production capacity, increasing labour costs, increasing fixed overheads, and, hence, the problems of capital investments. Necessities of competitive strategies for market segmentation and positioning was minimal. As such, strategy discourse was only implicit in the rhetoric of business policy, which attempted to address the congruence of the company's long -term goals with external environmental demands, and the operational efficiency, which attempted to enhance the cost efficiency through economies of scale. 
Constituting the classical views of business strategy, business policy view and industrial economics vies evolved from two distinct epistemological traditions. The first one, the business policy stream, emerged from the writings of Peter Drucker (1954), Igor Ansoff (1965), Thomas Cannon (1968), Learned et al. (1969) and alike, which, in their own way, conceptualised organisations as what Ansoff (2007 [1979]) subsequently came to label as "environmental serving organisations" (ESO) and strategic or corporate planning as the boundary spanning act that attempts to build an optimum fit between organisation's internal dynamics and its environmental dynamics. The quote below from Ansoff's (2007 [1979], 25) famous text on strategic management vividly explains this conception of strategy:

The commercial results realised by an ESO are largely determined by an alignment of
certain attributes. ... Part of this alignment is external between the level of environmental
turbulence and what we shall call the strategic thrust of the ESO. Another part is internal
between the strategic thrust and three attributes of the ESO: its strategic culture, its
managerial capability, and its logistic capability. [...] When the attributes are properly
matched, the potential performance is optimised; when they are not, the potential
deteriorates proportionally to the mismatch. [...] The performance is also influenced by
the resource commitment, the strategic budget, which the ESO makes to its strategic thrust.
The theory defines for each environment a strategic budget level, called critical mass,
below which the ESO cannot hope to realise a positive net commercial exchange with the
environment. Above the critical mass the ROI rises for a while as budget is increased, but
eventually levels at a maximum.

The second stream of strategy concerns developments in industrial economics, especially regarding theories relating to industrial organisations and writings on connections between the structural conditions firms faces and the marketing and production decisions firms should make. Although traditional business policy literature conceived the environment broadly and thus included various stakeholder dynamics and power statuses, the industrial economic conception of the competitive environment remained mainly confined to the 'industry or the market structure'. As such, the idea of strategy mostly concerned how industry structure determined firms' conduct and thus performance; hence, it assumed a structural dependency of the latter on the former. Examples include the Bain (1968), and Mason (1956) models of structure conduct -performance, which deem not only that industry structure determines an individual firm's conduct but also that firms' collective conduct determines the market and industry performance. While the notion of 'conduct' here captures a firm's choices regarding key decision variables such as price, quantity produced, capacity utilisation, level of product and service quality, and advertising, the focal attention of industrial economics was primarily on not the notion of strategy or the specific decisions firms make but industry or market performance (see, Alawattage and Wickramasinghe 2019; Porter 1981). Here, the notion of performance was seen from an economists' perspective rather than a managerial one, with the focus on "social performance, encompassing dimensions such as allocative efficiency (profitability), technical efficiency (cost minimisation), and innovativeness" (Porter 1981, 611). This structure-conduct -performance archetype generally converged with the business policy perspective when applied in the context of oligopoly industrial structure, especially when viewed through the analytical prism of game theory (see Schelling 1960; Von Neumann and Morgenstern 1944). Because of the specific nature of the industrial structure under consideration, attention was on firm -to firm rivalry - that is, the way a firm reacts to competitive moves by optimising its own performance in terms of market share and profitability.

A common thread binding these two streams of strategy discourse is that both viewed strategy from an 'economising' perspective in terms of enhancing corporate value as accounted by the ROI. Hence, they both demanded managerial emphases on minimising average cost by enhancing optimum capacity and utilising and increasing sales by product and market diversifications. Also, they both retain the doctrines of mass production and mass marketing upon which economic efficiencies can be achieved and ROI maximised. The popularisation of the DuPont system of ratio analysis, product and industry life cycle analysis, and Igor Ansoff's product -market diversification grid as corporate planning tools was the cumulative manifestation of this collective understanding. As we will be further elaborating on in the forthcoming sections, these tools provided the initial seeds for subsequent neoliberal developments of strategy discourses. Especially before Michael 
Porter's neoliberal reinventions of strategy discourses, BCG growth share matrix and alike (e.g. GE nine cell matrix) converged this pre neoliberal understanding of strategy into analytical models of business portfolio planning through which capital flows within $\mathrm{M}$-form organisational structures were to be optimised.

Therefore, broadly speaking the liberal faith of strategy has deep roots in the neo classical economic doctrines of economies of scale oriented towards mass production and mass marketing. These were to be achieved through product and market diversification strategies in the realm of market, capacity enlargement through mergers and acquisitions that created multi divisional organisational structures in the realm of hierarchy, and bureaucratic controls and standardisation at the point of production. And they were, one way or the other, driven towards inventing and reinventing 'productive and efficient spaces of disciplinary confinements' wherein bodies were disciplined for the purpose of capital accumulation, as accounted by ROI, the "signature of capitalism" (Bryer 2000a; see also Chiapello 2007).

\subsection{State of management accounting}

Strategic implications of management accounting need conceptualising based on how they help enable and enact strategies in four interrelated domains of strategic actions: market, hierarchy, point of production, and social and environmental (in contemporary neoliberal capitalism). Table 2 summarises management accounting's pre neoliberal centripetal form. It highlights the theoretical idea that management accounting as a practice was highly rooted upon the political necessities of liberal governmentality. As such, it was about enhancing the efficiency with which the labouring body is harmonised with the productive machinery of the disciplinary confinements (such as factory) that are defined and made visible in accounting terms. Calculative definition and evaluation of the disciplinary confinements was indeed the management accounting's political role.

Table 2: State of management accounting in the centripetal order

\begin{tabular}{|c|c|c|}
\hline $\begin{array}{l}\text { Domains of } \\
\text { strategic action }\end{array}$ & The conception of the domain of strategic action. & Dominant practices. \\
\hline Market & $\begin{array}{l}\text { Market is operationalised as an externality that needs to be } \\
\text { internalised through forecasting the demand and its sensitivity } \\
\text { to the price. Once internalised as demand estimates, the market } \\
\text { would provide the 'constraints' within which the functionality } \\
\text { of the productive cell, and the bodies confined within it, are to } \\
\text { be decided. Pricing is the dominant strategic action in the } \\
\text { market. }\end{array}$ & $\begin{array}{l}\text { Demand forecasting, costing, pricing, } \\
\text { and budgeting. }\end{array}$ \\
\hline Hierarchy & $\begin{array}{l}\text { As a hierarchy of cost, profit, and investment centres, } \\
\text { bureaucratically and calculatingly arranged towards the } \\
\text { investors'value maximisation through ROI. Directing conduct } \\
\text { towards profit maximisation/cost minimisation is the strategic } \\
\text { intention. }\end{array}$ & $\begin{array}{l}\text { Budgeting and management control } \\
\text { systems. }\end{array}$ \\
\hline $\begin{array}{l}\text { Point of } \\
\text { production }\end{array}$ & $\begin{array}{l}\text { As divisions of work and labour into specialities of labour so } \\
\text { that labour can be confirmed in specialised productive cells. } \\
\text { Seeking productive efficiency through standardisation is the } \\
\text { mode of operation. }\end{array}$ & $\begin{array}{l}\text { Time and work standardisation; } \\
\text { standard costing; time scheduling of } \\
\text { work; and budgeting and variance } \\
\text { analysis. }\end{array}$ \\
\hline $\begin{array}{l}\text { Social and } \\
\text { environmental }\end{array}$ & Taken for granted and ignored. & Rarely developed. \\
\hline
\end{tabular}

The growth of industrial capitalism was predominantly characterised by the invention and reinvention of the point of production and the hierarchy, but not the markets. In fact, the market was mainly conceived as a structural condition for the political state to modulate, govern, and guide towards 'perfect competitions'. This was the idea established in neo classical economics, especially its structure conduct performance model (see Bain 1968; Mason 1956; Porter 1981), had established for many decades. In it, the market was not seen as a site in which the firm can exercise its strategic agency; instead, it was deemed a structural imposition upon which the firm needs to optimise its operational parameters, especially its capacity utilisation and pricing decisions. In calculative terms, the market appears to managerial rationalisation as the demand - as the causal connection between the prices that firms can set and the possibilities of revenue. Accordingly, the strategic action is about forecasting and estimating the demand, which then taken to be the "market constraint' subject to which firms should programme their conduct. As such, management 
accounting calculations such as cost $\sim$ volume $\sim$ profit analysis and budgeting provided calculative rationalisations for aligning firms' conduct with the market.

The hierarchy's political functionality was to provide a command, information, surveillance, and a calculative structure through which individual conduct is organised into the collective conduct of earning a satisfactory ROI. To this end, the hierarchy ensembled a set of disciplinary principles and mechanisms through which the labouring body was put into a continuously disciplinary gaze that directed its performative actions. Notably, this gaze was calculative, as the conduct of the individual and collective body is made visible through the calculations hierarchically arranged with the management accounting constructs of cost, profit, and investment centres. Hierarchy is thus a calculative structure of capital accumulation. Management accounting evolved to serve the capitalistic hierarchy in three distinct forms: as a system of calculative justification (i.e. evaluating which actions best serve ROI); as a system of calculative structuring and surveillance (i.e. partitioning and grouping people, things and their actions/outcomes for calculative observations and judgements); and, thereby, as a calculative system of subsuming labour to the interest of capital accumulation at the point of production.

From a governmentality perspective, governance encompasses disciplining bodies within special purpose self $\sim$ enclosed locations to contain individuals within a monotonous disciplinary state with a particular mode of objectivation and subjectivation (see Foucault 1979; Hopper and Macintosh 1993). While schools, hospitals, prisons, military barracks and alike constitute such disciplinary enclosures, the factory has been the signatory disciplinary confinement of capitalistic value creation. Indeed, the factory confines labouring bodies in time spatial arrangements wherein they are subject to "governing by numbers" (Miller 2001; Rose 1991). The factory is also an assemblage of 'productive cells' that constitute the economy's grassroots elements, so here "the art of exercising power in the form of economy" is materialised through the time space -body connections these cells enable and enact. This "art of exercising power in the form of economy" is calculative to the extent that the productive functions and outputs of these productive cells are defined in accounting terms - for example, a machining centre 'standardised' in terms of its hourly production targets. It is in relation to the productive cell's calculative attributes that it becomes possible to know, master, and make the individual governable and useful. As Table 2 summarises, this was the disciplinary and anatomico political functionality that management accounting assumed since its inception. This political functionality of management accounting still holds, but management accounting's recent strategic turn has enabled and enacted a concurrent biopolitical functionality of centrifugal circulation beyond the disciplinary confinements.

\section{Neoliberal trends}

\subsection{Historical contours: the emergence of biopolitical markets}

Standing on Foucault's theoretical ideas, we view strategising management accounting within the context of the historical shift from the disciplinary milieu to the biopolitical one mentioned above. This, in effect, involves a change in the mode of governmentality from disciplinary confinement to biopolitical circulation. And this transformation was equally politico ideological, institutional, and techno managerial. In this shift, the politico ideological context comes from neoliberalisation of the political state, globalisation of the market and institutional context, and digitalisation and virtualisation of the techno managerial context. Together, these contextual dynamics "cast the political and social spheres both as appropriately dominated by market concerns and as themselves organised by market rationality [...] the state itself must construct and construe itself in market terms, as well as develop policies and promulgate a political culture that figures citizens exhaustively as rational economic actors in every sphere of life" (Brown 2006, 694). The first political principle upon which neoliberal governmentality evolved (and hence strategising form of management as well) is the signification of the 'economic' (over the political and social). As Foucault (2008, 84, emphasis ours) spells it out:

the economy, economic development and economic growth, produces sovereignty; it produces political sovereignty through the institution and institutional game that, precisely, makes this economy work'. The economy produces legitimacy for the state that 
is its guarantor. In other words, the economy creates public law, and this is an absolutely important phenomenon, which is not entirely unique in history to be sure, but is nonetheless a quite singular phenomenon in our times. [...] This economic institution, the economic freedom that from the start it is the role of this institution to guarantee and maintain, produces something even more real, concrete, and immediate than a legal legitimisation; it produces a permanent consensus of all those who may appear as agents within these economic processes, as investors, workers, employers, and trade unions. All these economic partners produce a consensus, which is a political consensus, inasmuch as they accept this economic game of freedom.

The focal point of attention here is the "institution and institutional game that makes this economy work", as it is through this that political legitimacy and consent are produced. Also, this game pervades every realm of our social lives to establish the market logic as the dominating logic of governance. In this neoliberal regime of governmentality, the market receives a new and different set of forms, meanings, functionalities, and associations. As we have well been taught by neo classical economics, by conventional forms of management accounting, and by Marxist labour process theorists, the market exchange is where the surplus value is valorised. Of course, this is a fundamental role the market plays, and from it other political functionalities of the market stem. Nevertheless, seeing the market from the theoretical angle of governmentality helps to understand how the market would become an institution of governance, and with this one should realise that the market performs two fundamental functions of governance: jurisdiction and veridiction.

Indeed, with its institutional and techno managerial inventions, neoliberalisation has entrusted the market with the political role of jurisdiction more than ever before. The market now performs this political functionality by transforming itself into a disciplinary ensemble in at least three interrelated ways: regulation, sanction of frauds, and just price (see Foucault 2008, 30 31). Regarding regulation, as a self $\sim$ governing institution that also governs the others, the market has now absorbed much of the regulatory functions the political state used to do over the market. In other words, there has been an explosion of the boundaries between the political state and the market, and from this the market is reformulated as the neoliberal regulatory infrastructure which "operates under the assumption that the market can provide regulatory services because they are valued by market participants" (Booth 2019, 7). As such, under the neoliberal logic of governance the political state's role is redefined as supporting and reinforcing the market, and in this it collaborates with the market so that the market can form its own regulatory apparatuses for self governance [as in the case of the formation of the Independent Press Standards Organisation in the UK to self $\sim$ regulate the mass media, for example]. Hence, the market is more than a mere transactional space. It is an assemblage of institutions that defines what it means to be a 'player' in the competition and, thereby, deploys the political principles of regulatory justice. This form of justice ensures social actors participating in market activities (which are now no longer simply confined to exchanges of goods and services but encompass all sorts of informational and jurisdictional activities such as rating, ranking, commenting, and passing judgements on each other) are governed by a common set of regulatory doctrines, codes of conduct, principles, and protocols. Such regulatory elements stem not directly from the state as laws of the sovereign but from the institutions that self $\sim$ contain the market, and the political state facilitates their initiation and independent operation.

This regulatory ensemble is then directed towards the two jurisdictional aims of sanction of frauds and just price. To be a site of justice, and to ensure it performs its role of distributive justice, the market, through its regulatory ensemble, should, or at least try to, mitigate possibilities of theft and crimes. The buyers and sellers, as well as the market's general integrity, need protecting from possible frauds. Indeed, given complicating technological conditions, one of the greatest challenges of neoliberal capitalism concerns protecting markets from the counter flow opportunities they themselves create. Issues such as money laundering, human trafficking, modern slavery, scamming and hacking, to name the most apparent, have become critical strategic issues of our time that need addressing. The prices the markets set would become 'just' only to the extent that the market regulates conduct and sanctions fraud. 
Therefore, as Miller $(2010,56)$ argues, neoliberalism means not less state intervention but more, as the "grand contradiction of neoliberalism was its passion for intervention in the name of non intervention [...] hailing freedom as a natural basis for life that could only function with the heavy hand of policing by government to administer property relations". However, in the process of this intervention, the state (or rather, as Foucault puts it, "the art of government" rather than the state itself, which has no essence other than its mode of operation) is to be subsumed by the market, and the political states' role is redefined as not to govern the market but to facilitate the market to govern itself and others. As such, it is not that the market is regulated; it is that the market is regulation. Market as an institutional ensemble absorbs everyone and everything into the market logic of conducting their conduct.

The market being a site of veridiction is about producing truth regarding conduct. To this end, the markets are now populated by epistemic institutions and technologies that reproduce the markets as data, as this or that form of knowledge/truth about market incumbents' performance. And it is against this market $\sim$ created truth (e.g. stock market prices and other indexes, averages, and benchmarks) that individual and collective performances and conduct are now continuously monitored, evaluated, and judged. Consequently, as Foucault $(2008,32)$ explains, "the market determines that a good government is no longer quite simply one that is just. The market now means that to be good government, the government has to function according to [the] truth" the market establishes.

This neoliberal reconstruction of the market to be veridictional and jurisdictional is not only politico ideological and institutional but also techno managerial. Having formed into an ensemble of regulatory and epistemic institutions, the market has been enabled via advancements in information technology to perform this veridiction role on a large scale by transforming itself into a massive accounting machine. It continuously creates voluminous 'performance data' against which social actors can benchmark and assess their performance online and in real time. Indeed, the markets have become 'informational grids' upon which social actors' continual gaze is placed as a reference point for indexing these actors' own performance. The market has become constantly 'visible', making it a different ontological being. It exists as an 'epistemic object' (see Cetina and Bruegger 2000; Zwick and Dholakia 2006), often appearing on computer screens. Zwick and Dholakia $(2006,48)$ explain,

With the introduction of the market on screen, geographically remote and technologically dispersed exchange relations were assembled and aggregated, making the market available and recognisable as a unique creature. The aesthetics of the screen turned the market into an entity in its own right for the first time by appresenting knowledge and information - prices, risks, ratios, interpretations, gains, and losses and other relevant information - in one place ... The boundaries of the screen configure a 'whole' market and an interactive market and most of all, a market that continually morphs, moves, and changes before one's own eyes.

By becoming so visible, the market has now become "heterotopian" (see Foucault 1986). That is, it has become a counter site, a kind of effectively enacted utopia in which all other real sites are simultaneously represented, contested, and inverted (cf., Foucault 1986, 24). As they are today in databases and on screens averaging/aggregating and individualising market participants' performance, markets are placeless places that operate like what Foucault calls a heterotopian mirror. The market is a subtle mixture of the utopia and the real - a subtle construction of a utopian view of 'ourselves' through what is projected as real in terms of data. Like a mirror, the market reflects a utopian view for managers of what their corporation should be and what their performance ought to be in comparison to the average and best performance indicators provided by the statistical grids in which the market represents itself. As Foucault (Foucault 1986, 24) writes,

In the mirror, I see myself there where I am not, in an unreal, virtual space that opens up behind the surface; I am over there, there where I am not, a sort of shadow that gives my own visibility to myself, that enables me to see myself there where I am absent: such is the utopia of the mirror. 
Similarly, statistical grids and on screen data, which we now call the market, enable managers to see themselves, their corporate performance, where they are absent, in a particular ideal point as a datum on the market grid depending on the reality the data reveal to exist. For example, this may be a dot in the top right corner of the high high quadrant of a two dimensional strategic map or a data point among the top $10 \%$ of the market league tables. So, the market simultaneously realises and idealises performance. This idealisation is not wholly utopian but heterotopian, because the reality the market as an accounting machine creates drives it.

The market's disciplinary projection is pervasive. TV channels such as Bloomberg continuously and endlessly project the markets to us. The dean of the faculty, for example, sends us an email detailing National Student Survey data and highlights where we are and where we want to be. Strategies would then follow to present ourselves where we are now absent. In myriads of ways, summarised into various matrixes to be discussed and addressed in multiple boards, committees, and forums, the markets are all over us, demanding us to continuously reform our conduct to match the competitive conditions the market projects to us as 'performance data'. One critical organisational response to this overwhelming neoliberal markets is strategising, which we discuss in the next section.

\subsection{Faith of strategy: biopolitics of competitiveness}

Strategising was a biopolitical response to the neoliberal signification of markets. Biopolitics involves continuously reinventing pathological issues at the political economy level then connecting them to anatomico politics at micro organisational and cognitive levels. "Biopolitics will derive its knowledge from, and define its power's field of intervention in terms of [pathological issues such as] the birth rate, the mortality rate, various biological disabilities, and effect of the environment" (Foucault 2003, 245). In other words, biopolitics involves constructing the political economy as an accounting entity and bringing its pathologies to the forefront of political discourse to necessitate epistemic intervention and regulation by the state and the market. This intervention is simultaneously biopolitical and anatomico political. At the biopolitical spectrum, political economy is accounted for as a "problem that is at once scientific and political, as a social body that is at once present as a biological problem and a problem of power" (Foucault 2003, 245). At the spectrum of anatomico politics, it involves the discursive connection of micro entities to the political economy's pathologies. Neoliberal governmentality is about making this connection between the biopolitical and the anatomico political: between the macro and the micro; between the political and the scientific (which appears as managerial in organisational sciences). Technologies of regulation are the techno managerial means through which this connection is established.

In the early 1980s, strategic management discourses became widespread alongside the biopolitical reinvention of 'competitiveness' as a pathological problem of western political economies, with the latter subsequently and reciprocally redefining strategy as a new field of biopolitical intervention. In particular, in the Anglo American context a new intellectual and institutional agenda was started to bring the notion of 'competitiveness' to the forefront of political discourse as the most critical biopolitical problem. Michael Porter (ref), in his testimony to the US House of Representatives, argued that the most fundamental political "challenge is competitiveness, not jobs per se". The losing competitiveness of the US and European economies, especially against Japan and other East Asian economies, was propagated as graver and more fundamental than health, poverty, education, welfare, crimes/criminality, homelessness, and so on. While Chicago school economists played a critical role in establishing neoliberalism as the dominating political economic ideology of our times, Porter and other Harvard academics (and US strategy gurus in general) played a significant role in constructing the "The Looming Challenge of Competitiveness" (see Porter and Rivkin 2012) as the most critical political criterion against which many other social and political elements of our societies should now be judged. As such, competitiveness is accounted for as a political problem, as a problem that is at once scientific and political, as a pathological trait of the collective social body that at once presents as a biological problem (of the individual and organisations) and a problem of power and governance (cf., Foucault 2003, 245). The political efficacy of things like tax, education, democracy, employment rights and contracts, trade unions, and, also, the political administration 
were discoursed to be judged on the basis of their contribution to the competitiveness of the nation's multinational firms.

To discursively reiterate and reinforce the pathology of competitiveness, strategy gurus constructed a particular epistemic infrastructure from certain institutions and practices such as the Institute of Strategy and Competitiveness (Harvard Business School), Harvard Business School's US Competitiveness Project Surveys, and the World Economic Forum and its Global Competitiveness Report. By design, these epistemic elements were primarily for the discursive construction and political signification of a particular neoliberal understanding of the problem of competitiveness. For example, Harvard Business School's US Competitiveness Project Surveys solicited the views of Harvard Business School alumni and other similar categories of people with an inherent business bias on the state of competitiveness. Such views are then presented at once as scientific and political, "as a multi year, fact -based effort to understand the disappointing performance of the American economy, its causes, and steps needed by business and government" (Porter et al. 2016, 2). To register it in the political elites' collective minds, the pathology of competitiveness and the necessity of 'strategy consultation' are discoursed and established. For example, in their 2016 survey Porter et al. $(2016,2)$ repeated the problem as follows:

\begin{abstract}
U.S. competitiveness has been eroding since well before the Great Recession. America's economic challenges are structural, not cyclical. The weak recovery reflects the erosion of competitiveness, as well as the inability to take the steps necessary to address growing U.S. weaknesses ... Our failure to make progress reflects an unrealistic and ineffective national discourse on the reality of the challenges facing the U.S. economy and the steps needed to restore shared prosperity. Business has too often failed to play its part in recent decades, and a flawed U.S. political system has led to an absence of progress in government, especially in Washington.
\end{abstract}

The point here is not whether US competitiveness (or that of any other country for that matter) is actually eroding or not, which may or may not be the case. It is about the way strategy discourses constructed 'competitiveness' as the greatest problem of this neoliberal time and the way state bureaucracy and political leadership are condemned to create an institutional and political vacuum that is to be filled by consultocracy, management gurus, and corporate leaders (see Kantola and Seeck 2011; Saint Martin 2000).

Strategy discourses, with their competitiveness mantra, project and signify the management gurus and corporate leaders as the ultimate source of wisdom on the basis of which the neoliberal governance is to be formulated and reformulated. In essence, these discourses were to replace political leadership with business leadership, democracy with technocracy, and bureaucracy with consultocracy so that they become the epistemic and political apparatuses according to which the state should formulate its political economic policies. Porter and his colleagues' institutional initiatives exemplify this. For example, (Porter et al. 2016, 4 5) "economic strategy for Washington" mobilises the epistemic and institutional power of the Harvard Business School alumni to articulate a biopolitical position:

A large majority of HBS alumni believe the political system is obstructing US economic growth and competitiveness. Many alumni who self $\sim$ identified as Democrat or Republican blame the other party, but a sizable proportion also hold their own party responsible [...] Overall, we believe that dysfunction in America's political system is now the single most important challenge to U.S. economic progress. [...] The top corporate tax problems, according to the surveyed business leaders, are the high corporate tax rate and the taxation of international income. Business leaders report overwhelming and bipartisan support (over 95\%) for corporate tax reform. Consensus corporate tax reforms include reducing the statutory rate by at least 10 percentage points, moving to a territorial tax regime, and limiting the tax free treatment of pass -through entities for business income. The transition to a territorial regime should be complete, not half $\sim$ hearted via the inclusion of an alternative minimum tax on foreign income.

What we see in such strategy discourses is the way they create a particular knowledge power regime in which two pertinent things happen: (a) democratic political processes and institutions are 
discredited as inefficient, out of date, and out of touch; and (b) business leaders are discursively reconstructed as non or anti political figures who, nevertheless, have a superior epistemic capacity and credibility than political leaders. Hence, these discourses assert that nations need to follow what top corporate managers and alumni of leading Business School think about what is best for themselves, with the assertion being that what is good for them is necessarily good for the public and nations. Finding solutions to the problem of losing competitiveness is thus entrusted with the new marketised wisdom of consultants, corporate leaders and strategy gurus, who now appear as those through whom the divine markets now speak (see Nelson 1991, 2001). The political wisdom of managing the economy, polity, and civil society was thus packaged into various consultancy frameworks, models, and programmes of change management and strategy. In sum, this is bio politicisation of business wisdom, which Kantola and Seeck $(2011,26)$ explain:

In liberal market democracies, politics is a field of democratic and civic participation, discussion, disagreement and conflict ... However, management ideas, on the contrary, often suggest that there is one best practice for political problems and tend to play down opinionated political discussion and conflicts and replace them with a carefully packaged management scheme, which is presented as unquestionable expert knowledge. This worry has become all the more pervasive as the growing importance of management practices in the running of the state has been paralleled by a growing sense of politics as something that is opposite to management; something negative or even harmful.

\subsubsection{Porterian discourse of strategy: a biopolitical hierarchy of competitiveness}

Porterian discourse has been the most dominating and characterising of the strategy discourse in neoliberal times, and it has created a particular historical trajectory and a schema of 'competitiveness' for connecting the biopolitical with the anatomico political. This trajectory starts with Porter's early work (e.g., Porter 1981), where he reformulated the structurally deterministic "structure conduct -performance" model (see Bain 1968; Mason 1956). Before Porter's reformulation, being the dominating framework in industrial policymaking, this model established the idea that industry structure ultimately determines firms' 'conduct' and their collective performance; hence, strategic actions should be directed towards 'perfecting' market/industry structures through macroeconomic and industrial policies. Corporate leadership and strategy were not offered a significant political role in national politics and economic policymaking. Porter reformulated this model and provided corporate leadership and strategy with the necessary strategic agency over structure, which was an epistemic necessity if strategy discourses were to be uplifted to the political status of biopolitical interventions. Converging the fields of industrial economics and business policy, Porter then promoted the idea that corporate strategies determine firms' individual and collective performances and the 'competitive advantage of the nation' (Porter 1980; Porter 1985; Porter 1990). He popularised a conceptual schema through which a nation's competitive advantage connects to that of the firms and the strategic actions and processes corporate managers adopt. This was, in effect, neoliberalisation par excellence: making 'competitive advantage' the political morality of the neoliberal political economy, strategy as the political technology, and strategy discourses as the knowledge power nexus upon which the connection between that morality and technology is to be established. This schema of strategy enables and enacts neoliberalisation at its best by connecting everything to the strategies according to which corporations compete.

Porterian discourse manifest a particular 'biopolitical hierarchy' of concepts pertaining to competitiveness (see Figure 1). At the top of this hierarchy is the notion of the "competitive advantage of a nation", which puts nations into competition and comparison. Porter, his colleagues, and other global neoliberal epistemic institutions (e.g. World Economic Forum) developed the necessary calculative basis where by this concept became a 'technology of regulation' in forms such as the Global Competitiveness Index ${ }^{1}$. While predominantly being organisational level discourses of

\footnotetext{
1 The World Economic Forum publishes the Global Competitivness Index in its much celebrated annual publication titled The Global Competitiveness Report. This index (as reformulated by Xavier Sala $\sim \mathrm{i} \sim$ Martin and Elsa V. Artadi in 2004 World Competitiveness Report) integrates Jeffrey Sachs's Growth Development Index and Miachel Porter's Business Competitivness Index (see World Competitivness Report 2004).
} 
strategising, Porterian discourses of strategy have maintained their biopolitical relevance through indexing competitiveness (and hence corporate strategy) as a political economic problem of the nations. Competitiveness is thus presented simultaneously as a biopolitical problem associated with nation $\sim$ states and a anatomico political problem associated with the micro management of organisations as a value chain, value chain being the bottom end of the biopolitical hierarchy of competitiveness so created.

Figure 1: a biopolitical hierarchy of competitiveness

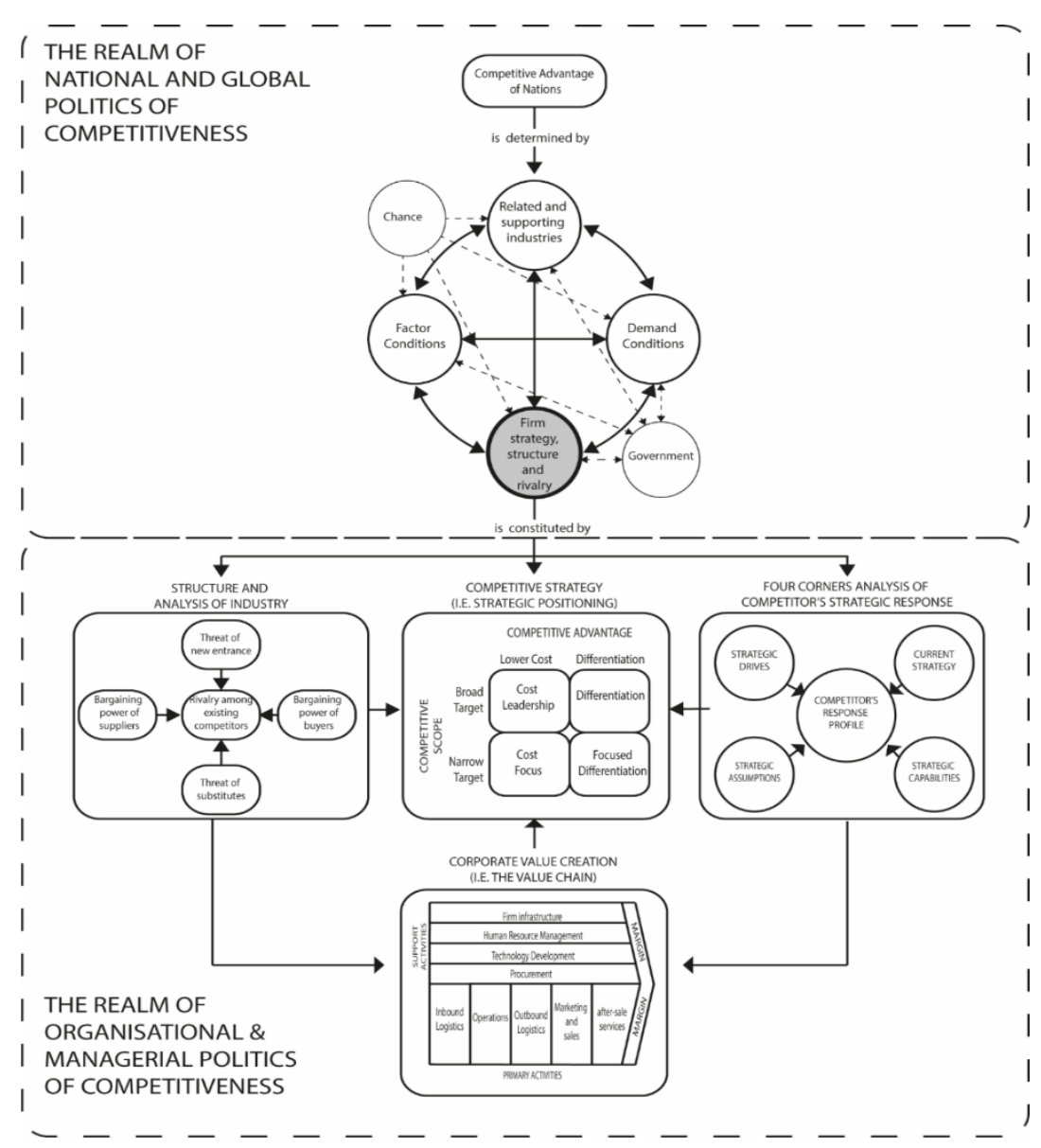

Between the biopolitical and anatomico political ends of the nation and the corporate value chain lies a series of structural conditions and schemas of structural analysis. In these Porterian discourses, the notion of structure now takes a neoliberal twist. As we mentioned earlier, a key political economic doctrine of neoliberalism is the idea of entrepreneurial agency and freedom, which translates into "the entrepreneurial self" (see Cooper 2015) at the level of individuals and "strategic organisations" at the level of firms. So, the neo classical economic idea that 'structure determines' cannot be a fundamental doctrine in neoliberal ideology and politics. Accordingly, our analysis of Porterian discourses tells us that structure is now presented as a set of collective forces that offers "opportunities" for individuals and firms to be entrepreneurial if, and only if, firms and individuals are capable of capitalising on those opportunities by being strategic. Being strategic then requires a series of analyses and rationalisations to identify how structural forces open up opportunities for firms and individuals to "position" and "differentiate" themselves from their competitors in these structural conditions. According to Porter (see Porter 1980, 1985, 1996, 2004), it is this capacity to "differentiate" that brings "competitive advantages" to the firms and

Progress and development is now to be equated and measured by 'competitivness' - the ultimate political doctrine of neoliberalism. 
their nations, the advantage upon which a nation's capacity to solve the "looming problem of competitiveness" resides.

\subsubsection{Neoliberal disciplinarity: anatomico politics of neoliberalism}

Neoliberal strategy discourses redefine the anatomico politics of disciplinarity in the context of the "value chain", which is the institutional form into which the labour process is now reconceptualised. As we mentioned earlier, in liberal forms of the anatomico politics of confinement, labour is to be synchronised with production machinery using Taylorist and Fordist 'scientific standards' of deskilling. In contrast, neoliberal reconceptualisations of the labour process demand that labour is responsive to the dynamism of market competition. Three interrelated elements - quality, flexibility, and cost - are then signified as the "strategic imperatives" that enable and enact the "strategic connection" between the value chain and the market. Various managerial techniques and processes ranging from Porter's value chain analysis through a collection of Japanese management concepts (e.g. target costing, kaizen, total quality management, just $\sim$ in $\sim$ time and so on) to zero hour job contracts were discoursed and popularised as an assemblage of regulatory technologies that can manage quality, cost, and flexibility. Focusing on the labour processes they were all aiming at, one way or another, institutionalising regimes of flexible manufacturing, quality management, and cost management.

The neoliberal notion of "flexible manufacturing" is a paradoxical concept. On the one hand, as in the case with any other neoliberal element, it aims at promoting competition among anyone or anything possible and aligning the actions, behaviours, and outcomes of everything and everyone with market dynamics. On the other hand, it demands coordination and cooperation among many parties through means ranging from political treatises for free movement of capital, labour, and materials such as the European Union and global standard setters to the supply chain management and micro organisational synchronisation and flexibilisation of labour and machines. Flexibilisation is simultaneously macro and micro, political and techno managerial, but, at its core, fundamentally it is about enhancing the firm's capabilities of dynamically creating 'value' in different forms for different market segments along with a faster response time to market changes. In this sense, the neoliberal labour process is a highly coordinated and cooperated site of reproduction in which labour is put into circulation with flexible machines and networks of communication. In this circulation of labour (vis à vis confinement), labour is to be "immaterialised" in the form of symbolic analytical labour, communicative labour, and affective labour (see Hardt and Negri 2000; Just 2016). These coordinated, cooperated, and immaterialised labour processes are realised through a hierarchy of political economic and techno managerial arrangements, as summarised in Table 3.

Table 3: Flexibilisation of the labour processes

\begin{tabular}{ll}
\hline Flexibility concept & Realm of operation and scope of analysis \\
\hline Flexible consumption & $\begin{array}{l}\text { The market } \sim \text { consumer and the consumer firm connection. } \\
\text { The consumer's ability and willingness to enjoy flexibility in their market } \\
\text { choices; the firm's strategic ability and willingness to offer opportunities for the } \\
\text { consumer to enjoy this consumption flexibility. }\end{array}$ \\
\hline Flexible machines & $\begin{array}{l}\text { The machinery's capacity to reschedule production at a minimum resetting cost } \\
\text { and time so that the economic order/production quantity (EOQ/EPQ) can } \\
\text { become just one. It is this fundamental technological possibility at the level of } \\
\text { the machine that technologically enables customisation and flexibilisation of } \\
\text { products in the market. CAD, CAM and other related networked technologies to } \\
\text { enable this reduction of the machine resetting time and cost. }\end{array}$
\end{tabular}

Flexible labour

Labour - firm level, techno managerial and political
Both intra and extra firm level techno managerial and political
transformations to enable the labour's capacity, willingness, and managerial
freedom to occupy and operate flexible machines in flexible time and space
locations. A spectrum of related or unrelated managerial and political actions
created the conditions of flexible labour (e.g. training and education for multi
tasking; deconstruction of the trade unions and organised labour; political
transformations to facilitate the free movement of labour across countries;
changes to labour law such as zero hour contracts; project - based hiring and
firing of employees).
Firm level - techno managerial


The particular manner in which a particular set of flexible labour, machines, and their interconnecting technologies is put together in a specific locality, network. and time-space.

Flexible specialisation and Industry/meso level - inter firm coordination into standardised industries.
integration This sort of industry level coordination for flexibility is achieved through, for example,

1. Various institutional arrangements for regulatory, governance, and standardisation so that firms across industries and supply chains need to produce their products (components) to specific standards in a way that ensures interchangeability of components for flexibility and customisation.

2. Supply chain management.

3. And various forms of inter firm arrangements such as regional conglomerates, federated enterprises, and solar firms and workshop factories (see Piore and Sabel 1984, 265 268).

This refers to neoliberal capitalism as a whole, where the flexibilisation of both capital and labour is the central proposition of accumulation. Flexible accumulation provides a particular theorisation of how circulation (through flexibilisation) of labour and capital becomes more crucial than disciplinary confinement. Inter alia, the global spatial reorganisation of labour into what Harvey (1990) calls the "core", "first peripheral group", "second peripheral group", and "third periphery" (see, Alawattage and Wickramasinghe 2019, 179 181).

\subsection{State of management accounting: the neoliberal reorientation}

Under neoliberalism, management accounting has become an ensemble of regulatory technologies and practices that enact and enable strategies in four interrelated domains of strategic actions: the market, the hierarchy, the point of production, and the discourses of sustainability (social and environmental). Table 4 summarises how it appears in these domains.

Table 4: State of management accounting in the centrifugal order

Domains of strategic

action

The market

The point of production The conception of the domain of strategic action

In biopolitical terms, the market encompasses all forms of enabling and enacting of the conditions under which lives are put into circulations as entrepreneurial selves. Management is focused on dynamically 'positioning' the firm and its brands, products, processes, activities, and people in such competitive conditions to achieve a "competitive advantage", which according to Porter is the firm's capacity to outperform its competitors. In our political economic viewpoint, 'competitive advantage' is the firm's capacity to achieve a greater rate of accumulation by playing out the market itself with or without a direct connection to the creation of surplus value at the point of production.

This is the point at which labour power is put into operations with productive machinery and other institutional apparatuses of surplus $\sim$ value creation. Traditionally, the operational doctrine was economies of scale through deskilling, mechanisation, and disciplinary confinement. In neoliberal capitalism, the point of production is reconfigured as 'internal markets', where labour now competes with each other, reinventing and re-identifying themselves into "entrepreneurs of the self". Also, labour is empowered with the capacity of performing 'immaterial labour'. The self is continuously subjugated to the technologies that enable competition at the point of production. Flexibility, quality and cost reduction are the defining concepts towards which the labour process is directed.

\section{Dominant practices/frameworks (i.e.} technologies of regulation)

Porterian industry analyses; competitor analysis; big data analytics and customer/market profiling; strategy mapping; target costing; value -chain analysis beyond the firm into supply chains; strategic pricing with segmentation, targeting and positioning (STP marketing); brand development.

Quality circles and similar quality management technologies, activity analysis, activity $\sim$ based

costing/management, just -in - time inventory management, target costing, enterprise resource planning, benchmarking, CAD CAM manufacturing, zero hour labour contracting, project-based recruitment of labour, heavy use of casual labour, outsourcing labour intensive activities of material labour to sweatshops in the third world. 


\begin{tabular}{|c|c|c|}
\hline The hierarchy & $\begin{array}{l}\text { Conventionally, hierarchy is the set of structural } \\
\text { and calculative relations that connects point of } \\
\text { production with ROI. To that end, hierarchy } \\
\text { enables and enacts flows of information and } \\
\text { commands that monitor and control operations } \\
\text { at the point of production. In neoliberal } \\
\text { capitalism, this is now reconfigured into } \\
\text { heterarchies, networks, and assemblages that } \\
\text { enable and enact market driven entrepreneurial } \\
\text { performance within and between institutions. }\end{array}$ & $\begin{array}{l}\text { Value chain analysis; balanced } \\
\text { scorecards; activity based } \\
\text { management; beyond budgeting; } \\
\text { supply chain management; ERP } \\
\text { practices; virtualisation technologies, } \\
\text { big data analytics, real time tracking } \\
\text { and tracing of the movement of goods } \\
\text { and people across networks and } \\
\text { supply chains. }\end{array}$ \\
\hline $\begin{array}{l}\text { The social and } \\
\text { environmental }\end{array}$ & $\begin{array}{l}\text { Neoliberal extensification and intensification of } \\
\text { capital accumulation, especially in the hands of } \\
\text { few at the cost of many, have created various } \\
\text { socio political and ecological issues. Similarly, } \\
\text { neoliberal capitalism has created various } \\
\text { 'counter flows' that challenge the stability and } \\
\text { the legitimacy of the system (e.g. money } \\
\text { laundering, human trafficking and modern } \\
\text { slavery, data security and risks issues, including } \\
\text { global pandemics). These have brought a new } \\
\text { set of 'biopolitical' themes and issues that } \\
\text { corporations and other organisations now have } \\
\text { to deal with accordingly. With the collapse of } \\
\text { the welfare state, some aspects of the welfare } \\
\text { economy now have to be internalised by the } \\
\text { corporate world to mitigate the cultural political } \\
\text { and environmental instabilities that neoliberal } \\
\text { expansion would create. }\end{array}$ & $\begin{array}{l}\text { Social and environmental reporting; } \\
\text { data protection and security } \\
\text { protocols; contingency and disaster } \\
\text { planning; regulatory compliance } \\
\text { with multiple global codes of } \\
\text { conducts, protocols and laws (e.g. } \\
\text { The Money Laundering and Terrorist } \\
\text { Financing (Amendment) Regulations } \\
\text { 2019; Modern Slavery Act 2015). }\end{array}$ \\
\hline
\end{tabular}

On the early evolution of management accounting, managerial attention was primarily on the control of labour process where Taylorism and Fordism played a critical role in shaping management accounting. Then through various waves of mergers and acquisitions (see Gaughan 2018), for example, firms grew into multi divisional firms, and managerial attention shifted to the organisational hierarchy to enable and enact ROI driven hierarchical control apparatuses such as responsibility accounting, the DuPont systems of financial analysis, and portfolio planning models. Now in this neoliberal regime of governance, managerial attention is primarily on strategic positioning in the market, encapsulating the necessity of being market oriented. The notion of 'strategy' is what makes management accounting market centric, and being strategic is often encapsulated by the idea of being market driven.

As such, to be strategic, management accounting's neoliberal rationalisation requires understanding the competitive conditions under which the firm operates. Accordingly, it is possible to determine the appropriate modes of differentiation that can bring a competitive advantage. This means that strategic management accounting is (or needs to be) externally oriented towards positioning firms within the competitive terrain, which is the logic many dominant strategic management accounting discourses (e.g., Kaplan 2008; Kaplan and Norton 1993, 1996a, 1996b, 2000; Simons 1995) have been popularising. Especially from the perspective of Johnson and Kaplan's Balanced Scorecards framework and Simons' Levers of Control Framework, the strategy is seen as the core doctrine that connects management accounting analyses with the realities of neoliberal markets.

A key conception of these neoliberal strategy discourses is that the neoliberal market is a competitive terrain in which multiple stakeholders' pluralistic demands are enabled and enacted. Hence, markets now operate with multiple logics ranging from financial to environmental, and management accounting rationalisations should be able to capture this multiplicity. The Balanced Scorecards, for example, try to capture this neoliberal conditionality through the strategic acts of "balancing" between the financial and non financial through multi dimensions of performance measurements and by "linking" strategy with operational planning through cascading scorecards (Kaplan and Norton 1993, 1996a, 1996b, 2000; see also, Cooper et al. 2017; Norreklit 2000, 2003)). Similarly, Simons' (1995) Levers of Control frame the ways a company can strategise the tensions between 'entrepreneurship and risk taking' on the one hand and 'regulation and control' on the other. Most recent strategic management accounting discourses relate to making this 
"strategic connection" between the markets' competitive dynamics and the internal business processes or the value chain.

Aligning the value chain with market dynamics demands that internal business processes and systems be flexible. To that end, in political economic terms, fixed capital needs reconceptualising into variable capital so that production capacity is readily amenable according to market dynamics. While activity based costing provided calculative rationality for this flexibilisation of capital, flexible machines, flexible labour and flexible manufacturing systems provided the necessary techno managerial conditions for it. Given that cost calculations manifest the efficiency with which capital is utilised, activity -based costing provided the necessary calculative basis for transforming hitherto 'fixed costs' into variable and, hence, controllable costs, opening the "black box" of managerial labour processes (see Armstrong 2002). Since the introduction of activity -based costing, and since the recognition that it is the activities which drive the costs, analysing activities in terms of their contribution to creating marketable value became a central theme in management accounting. Activity based management, value $\sim$ chain analysis, throughput accounting, quality costing, target costing and alike, one way or another, are related to this new strategic significance attributed to the 'activity valuation and management'. Techniques such as customer profitability analysis, lifetime customer value, lifecycle costing, benchmarking, and other similar techniques also received activity based refreshments. They all now constitute "strategic management accounting".

Nevertheless, neoliberalism is paradoxical. It is productive as well as destructive. While expanding global flows of commodities, labour and capital, it has resulted in massive "neoliberal counter flows" that can render the neoliberal political economic order unstable from within, and create Gros (2014) calls "the fourth or the global age of security". In this, all sorts of "security issues" that were dealt with in liberal capitalism as a "threat to the state" have now become issues to be dealt with by private entities as a "threat to the bios" (see Foucault 2008; Gros 2014). The defining characteristic of these new security challenges is that they are constituted by flows that neoliberalism enacted, enabled, and enhanced - for example, the flow of commodities, people, capital, energy, carbon emissions, news, images, data, and viruses. These flows constitute the threatening "counter flow" in the form of smuggling, trade dumping, money laundering, human trafficking, modern slavery, fake news, carbon emission and environmental pollution, the spread of biological and computer viruses, computer hacking and spamming, etc. In our field of study, these fourth global age biopolitical security issues are now captured by the notions of sustainability, governance, and ethics.

These issues are simultaneously intra and extra organisational, political and techno managerial. Mitigating them demands intra organisational processes and protocols as well as inter organisational collaborations. They demand techno managerial inventions as well as political initiatives across organisations and nations. In any case, biopolitical control implies flow control the control of movements and communications. Hence, as Gros $(2014,25)$ explains:

The problem becomes one of 'traceability': the ability to determine, at any given moment, what is moving, where it is coming from, where it is going, what it is doing in its current place, and if it actually has a right of access to the network in which it is moving or if its use of the network is unauthorised.

Management accounting and control, in this sense, has now been expanded beyond its conventional role of techno managerial compliance with the production and profits standards. Management control now encompasses regulations, governance, and ethical adherence to various 'security protocols' brought about by various international 'security networks' as manifested by, for example, UN Millenium Development Goals, Global Reporting Initiatives, Fairtrade Foundation, The Money Laundering and Terrorist Financing (Amendment) Regulations 2019, and Modern Slavery Act 2015. Neoliberalism has thus created new spaces of value creation and appropriation, but these are volatile and insecure. A salient feature of these new political economic spaces of value creation is that the conventional boundaries between the economic, political, and social have been blurred and conflated. Thus diluting itself into issues of security, governance and ethics, management accounting has now found new opportunities to spread its applicability beyond private corporations to various civil society and political organisations. 


\section{Summary and conclusions}

Building on the work of Alawattage and Wickramasinghe (2019), we have explored how management accounting is reformulated through neoliberal capitalism and its biopolitical technologies. We drew on Foucauldian ideas of biopolitics and neoliberalism to advance our argument that, in this neoliberal milieu of capitalism, it is the shift from the 'centripetal anatomico politics of confining the human body in productive cells' to the 'biopolitics of centrifugal circulation of lives' that has underlined the transformation of management accounting. We explored this through the interrelated themes of historical contours, faith of strategy, and the state of management accounting. Conventional management accounting was centripetal in that it primarily encapsulated the deployment of principles of disciplining the space, body, and time within institutional enclosures such as factories and offices. Accounting researchers (e.g. Hopper and Macintosh 1993) who took Foucauldian approaches illustrated how accounting techniques founded upon such disciplinary principles confine the body in various enclosures for capital accumulation. This liberal or modern disciplinarity was characteristically capitalistic to the extent that the normative aim of disciplining was capital accumulation. The overarching aim of management accounting was to subsume labour for the interest of capital accumulation amid labour's continuous resistance.

However, once neoliberalism was in its full swing since the late 1980 s those centripetal anatomico politics of confinement had to be reformulated by the centrifugal biopolitics of circulating lives and things. The biopolitics of circulation then reconstitutes management accounting in four interrelated directions: by absorbing the market into the calculative practices of management accounting; by lessening the tediousness of hierarchies and thereby allowing management accounting to be a responsive and fluid set of practices; by re inventing the point of production as a site in which labour now appears as entrepreneurs of the self, performing not only material but also immaterial elements of managerial labour; and by redrawing the scope of management accounting into the arenas of the social and the environmental.

Several critical aspects of this neoliberal reconstitution of management accounting can be pinpointed for future research. First, strategising management accounting occurs through the coexistence of both centripetal and centrifugal forces. We see that this coexistence can lead researchers to explore how anatomico politics would operate in relation to biopolitics and how this relationship implicates management accounting and control, or, inversely, how different techniques and practices of management control and accounting come into being to address the techno managerial and political economic problems and tensions that arise from the interplay between the centripetal and centrifugal forces of disciplining and value creation.

Second, this reconstitution has brought possibilities regarding management accounting's permeability into other bodies of expertise and biopolitical issues, including political governance, sustainable development, poverty alleviation, disaster management, and epidemic controls. This epistemological expansion is possible because of its new strategising form making management accounting malleable, responsive, and fluid. This means that it can readily flow into, account for, and manage issues that are more critical and demanding than 'shareholder wealth maximisation'. It was in the twentieth century when mechanical and industrial engineering practices were intermingled with cost accounting to form conventional management accounting, which, at that time, played a critical political role in establishing the new social order of modernity. A similar movement is now happening, but by intermingling with multiples epistemic sources in multiple spaces, addressing a wider set of issues in this "fourth era of global security" (Gros 2014). Critical accounting researchers should try to locate management accounting in such biopolitical issues of security that emanate from neoliberal expansion. The way management accounting permeates these spaces, reforming itself, is an interesting area of critical accounting research. Or in another way, this reminds of Miller (1998) when he argued that management accounting operates in margins and redraws boundaries to accommodate other practices or to operate in new territories. This opens up multiple paths for future researchers to study and understand how this permeability redraws management accounting's political landscape in line with new issues of security that contemporary transnational organisations, nation -states, and their organisations and citizens have to deal with. 
Finally, we must note that we did not want to argue that anything can be management accounting or management accounting is everywhere. Rather, we want to demonstrate that management accounting is still a calculative/rationalisation practice used for managing people and their activities at varying times and spaces. As we demonstrated, with strategising being the overarching trajectory, these practices are now organised malleably and fluidly because of neoliberalism's political and epistemological implications. As Wickramasinghe et al. (2021) have argued, management accounting penetrates new territories and is involved in apparently non accounting spaces in the form of offering calculative rationalisations in different types of assessments such as social media -based quality assessments and feedback, rankings, ratings, comments, and trending. Such extensions and deviations mark a remarkable transformation: while the things upon which management accounting acts are neoliberalised, management accounting itself is strategised, enabling the former to be strategised through management accounting. In this connection between neoliberalism and management accounting, the interconnection between biopolitics and anatomico politics plays a critical role. Indeed, it is in these evolving connections among anatomico politics, biopolitics, and strategising where researchers may locate their future research questions. They may see, we hope, possibilities for using not only the theoretical angles we have used here but also other alternative theoretical perspectives for constructive criticism and development of the agenda we set here.

\section{References}

Alawattage, C., C. Graham, and D. Wickramasinghe. 2019. Microaccountability and biopolitics: Microfinance in a Sri Lankan village. Accounting, Organizations and Society 72:38 60.

Alawattage, C., and D. Wickramasinghe. 2019. Strategizing Management Accounting: Liberal Origins and Neoliberal Trends. London: Routledge.

Andrew, J., and D. Cahill. 2017. Rationalising and resisting neoliberalism: The uneven geography of costs. Critical Perspectives on Accounting 45:12 28.

Andrew, J., and C. Cortese. 2013. Free market environmentalism and the neoliberal project: The case of the Climate Disclosure Standards Board. Critical Perspectives on Accounting 24 (6):397 409.

Ansoff, I. 1965. Corporate Strategy: An Analytic Approach to Business Policy for Growth and Expansion: McGraw $\sim$ Hill.

2007 [1979]. Strategic Management. Basingstoke: Palgrave Macmillan.

Armstrong, P. 2002. The costs of activity based management. Accounting, Organizations and Society 27 (1 2):99 120.

Bain, J. S. 1968. Industrial organization. New York: John Wiley \& Sons Inc.

Baud, C., and E. Chiapello. 2017. Understanding the disciplinary aspects of neoliberal regulations: The case of credit risk regulation under the Basel Accords. Critical Perspectives on Accounting 46:3 23.

Begkos, C., S. Llewellyn, and K. Walshe. 2019. Strategizing in English hospitals: accounting, practical coping and strategic intent. Accounting, Auditing \& Accountability Journal 32 (5):1270 1296.

Booth, P. 2019. Regulation without the state: the example fo financial services. In Institute of Economic Affiars Discussion Paper no.97: Institute of Economic Affiars

Bower, J. L. 1982. Business Policy in the 1980s. The Academy of Management Review 7 (4):630 638.

Braverman, H. 1998 [1974]. Labor and monopoly capital: the degradation of work in the twentieth century. 25th anniversary ed. ed. New York: Monthly Review Press. 
Brown, W. 2006. American Nightmare: Neoliberalism, Neoconservatism, and De Democratization. Political Theory 34 (6):690 714.

2015. Undoing the demos: neoliberalism's stealth revolution. New York: Zone Books.

Bryer, R. A. 2000a. The history of accounting and the transition to capitalism in England. Part one: theory. Accounting, Organizations and Society 25 (2):131 162.

.2000b. The history of accounting and the transition to capitalism in England. Part two: evidence. Accounting, Organizations and Society 25 (4 5):327 381.

Burawoy, M. 1979. Manufacturing consent: changes in the labor process under monopoly capitalism. Chicago; London: University of Chicago Press.

Cannon, T. 1968. Business Strategy and Policy: Harcourt, Brace \& World.

Cetina, K. K., and U. Bruegger. 2000. The Market as an Object of Attachment: Exploring Postsocial Relations in Financial Markets. The Canadian Journal of Sociology / Cahiers canadiens de sociologie 25 (2):141 168.

Chandler, A. D. 1963. Strategy and structure. Chapters in the history of the industrial enterprise. Cambridge, Mass.: M.I.T. Press.

Chia, R., and R. Holt. 2006. Strategy as Practical Coping: A Heideggerian Perspective. Organization Studies 27 (5):635 655.

Chiapello, E. 2007. Accounting and the birth of the notion of capitalism. Critical Perspectives on Accounting 18 (3):263 296.

43:47 64.

2017. Critical accounting research and neoliberalism. Critical Perspectives on Accounting

Chomsky, N. 1999. Profit over people: neoliberalism and global order. New York; London: Seven Stories Press.

Cooper, C. 2015. Entrepreneurs of the self: The development of management control since 1976. Accounting, Organizations and Society 47:14 24.

Cooper, C., M. Danson, G. Whittam, and T. Sheridan. 2010. The neoliberal project $\sim$ Local taxation intervention in Scotland. Critical Perspectives on Accounting 21 (3):195 210.

Cooper, D. J., M. Ezzamel, and S. Q. Qu. 2017. Popularizing a Management Accounting Idea: The Case of the Balanced Scorecard. Contemporary Accounting Research 34 (2):991 1025.

Cooper, D. J., and T. Hopper. 2006. Critical Theorising in Management Accounting Research. In Handbooks of Management Accounting Research, edited by C. S. Chapman, A. G. Hopwood and M. D. Shields: Elsevier, 207 245.

Drucker, P. F. 1954. The Practice of Management: Harper.

Foucault, M. 1979. Discipline and punish: the birth of the prison. 2nd Vintage Books. ed. New York: Vintage Books.

- 1986. Of Other Spaces. Diacritics 16 (1):22 27.

. 2003. "Society must be defended": lectures at the College de France, 1975 76. Translated by D. Macey. London: Allen Lane.

. 2008. The birth of biopolitics: lectures at the College de France, 1978 79. Basingstoke: Palgrave Macmillan.

Gaughan, P. A. 2018. Mergers, acquisitions, and corporate restructurings. 7 th ed. ed. Hoboken, N.J.: Wiley.

Gros, F. 2014. The Fourth Age of Security. In The Government of Life: Foucault, Biopolitics, and Neoliberalism, edited by V. Lemm and M. Vatter. New York: Fordham University Press, 17 28. 
Hardt, M., and A. Negri. 2000. Empire: Harvard University Press.

Harvey, D. 2005. A brief history of neoliberalism. Oxford: Oxford University Press.

Heifetz, A. 2012. Game Theory: Interactive Strategies in Economics and Management: Cambridge University Press.

Hopper, T., and P. Armstrong. 1991. Cost accounting, controlling labour and the rise of conglomerates. Accounting, Organizations and Society 16 (5 6):405 438.

Hopper, T., and N. Macintosh. 1993. Management accounting as disciplinary practice: the case of ITT under Harold Geneen. Management Accounting Research 4 (3):181 216.

Hopper, T., and A. Powell. 1985. Making sense of research into the organizational and social aspects of management accounting: A review of its underlying assumptions. Journal of Management Studies 22 (5):429 465.

Hopper, T., J. Storey, and H. Willmott. 1987. Accounting for accounting: Towards the development of a dialectical view. Accounting, Organizations and Society 12 (5):437 456.

Hoskin, K., and R. Macve. 1994. Reappraising the Genesis of Managerialism: A Re-examination of the Role of Accounting at the Springfield Armory, 1815 1845. Accounting, Auditing \& Accountability Journal 7 (2).

Hoskin, K. W., and R. H. Macve. 1986. Accounting and the examination: A genealogy of disciplinary power. Accounting, Organizations and Society 11 (2):105 136.

1988. The genesis of accountability: The west point connections. Accounting, Organizations and Society 13 (1):37 73.

Johnson, H. T., and R. S. Kaplan. 1987. Relevance lost: the rise and fall of management accounting. Boston, Mass.: Harvard Business School Press.

Just, D. 2016. A Biopolitics of Immaterial Labor. Political Studies 64 (2):401 416.

Kantola, A., and H. Seeck. 2011. Dissemination of management into politics: Michael Porter and the political uses of management consulting. Management Learning 42 (1):25 47.

Kaplan, R. S. 2008. Conceptual Foundations of the Balanced Scorecard. In Handbooks of Management Accounting Research, edited by A. G. H. Christopher S. Chapman and D. S. Michael: Elsevier, 1253 1269.

Kaplan, R. S., and D. P. Norton. 1993. Putting the Balanced Scorecard to Work. Harvard Business Review 1993 (September October):134 147.

_. 1996a. The balanced scorecard: translating strategy into action. Boston, Mass.: Harvard Business School Press.

_. 1996b. Using the balanced scorecard as a strategic management system. Harvard Business Review 1996 (January February):75 85.

2000. Having Trouble with Your Strategy? Then Map It. Harvard Business Review 2000 (September October):3 11.

Learned, E. P., C. R. Christensen, K. R. Andrews, and W. D. Guth. 1969. Business Policy: Text and Cases. R. D. Irwin.

Loft, A. 1995. The History of Management Accounting: Relevance Found: Prentice Hall.

Marx, K. 1990 [1867]. Capital: a critique of political economy, Volume One. Translated by B.

Fowkes. London: Penguin Books in association with New Left Review.

Mason, E. S. 1956. Market Power and Business Conduct: Some Comments. The American Economic Review 46 (2):471 481.

McKiernan, P. 1997. Strategy past; strategy futures. Long Range Planning 30 (5):790 798. 
Miller, P. 1998. The margins of accounting. European Accounting Review 7 (4):605 621.

. 2001. Governing by numbers: why calculative practices matter. Social Research 68 (2):379 396.

Miller, P., and T. O'Leary. 1987. Accounting and the construction of the governable person. Accounting, Organizations and Society 12 (3):235 265.

1993. Accounting expertise and the politics of the product: Economic citizenship and modes of corporate governance. Accounting, Organizations and Society 18 (2 3):187 206.

1994. Accounting, "economic citizenship" and the spatial reordering of manufacture. Accounting, Organizations and Society 19 (1):15 43.

Miller, P., and N. Rose. 1990a. Governing economic life. Economy and Society 19 (1):1 31.

—. 1990b. Governing economic life. Economy and Society 19 (1):1 31.

2008. Governing the Present: Administering Economic, Social and Personal Life: Wiley.

Miller, T. 2010. Michel Foucault, The birth of biopolitics: lectures at the Collège de France, 197879. International Journal of Cultural Policy 16 (1):56 57.

Moisander, J., C. Groß, and K. Eräranta. 2018. Mechanisms of biopower and neoliberal governmentality in precarious work: Mobilizing the dependent self $\sim$ employed as independent business owners. Human Relations 71 (3):375 398.

Munro, I. 2012. The Management of Circulations: Biopolitical Variations after Foucault. International Journal of Management Reviews 14 (3):345 362.

Nadesan, M. H. 2008. Governmentality, biopower, and everyday life. London: Routledge.

Neimark, M., and T. Tinker. 1986. The social construction of management control systems. Accounting, Organizations and Society 11 (4 5):369 395.

Nelson, R. H. 1991. Reaching for Heaven on Earth: The Theological Meaning of Economics. Lanham, MD: Rowman \& Littlefield Publishers.

2001. Economics as Religion: From Samuelson to Chicago and Beyond. Pennsylvania: Pennsylvania State University Press.

Niou, E., and P. C. Ordeshook. 2015. Strategy and Politics: An Introduction to Game Theory: Taylor \& Francis.

Norreklit, H. 2000. The balance on the balanced scorecard a critical analysis of some of its assumptions. Management Accounting Research 11 (1):65 88.

. 2003. The Balanced Scorecard: what is the score? A rhetorical analysis of the Balanced Scorecard. Accounting, Organizations and Society 28 (6):591 619.

Peck, J., and A. Tickell. 2002. Neoliberalizing Space. Antipode 34 (3):380 404.

Piore, M. J., and C. F. Sabel. 1984. The second industrial divide: possibilities for prosperity: Basic Books.

Porter, M. E. 1980. Competitive Strategy: Techniques for Analyzing Industries and Competitors: Free Press.

Porter, M. E. 1981. The Contributions of Industrial Organization to Strategic Management. The Academy of Management Review 6 (4):609 620.

Porter, M. E. 1985. Competitive advantage: creating and sustaining superior performance. New York: Free Press.

Porter, M. E. 1990. The competitive advantage of nations. New York: Free Press.

Porter, M. E., and J. W. Rivkin. 2012. The Looming Challenge to U.S. Competitiveness. Harvard Business Review 2012 (March):54 62. 
Porter, M. E., J. W. Rivkin, M. A. Desai, and M. ERaman. 2016. Problems unsolved and a nation divided: the state of US competitiveness 2016 including findings from Harvard Business School's Survey on US Competitiveness. Boston: Harvard Business School.

Rose, N. 1991. Governing by numbers: Figuring out democracy. Accounting, Organizations and Society 16 (7):673 692.

Roslender, R. 1995. Accounting for Strategic Positioning: Responding to the Crisis in Management Accounting1. British Journal of Management 6 (1):45 57.

- 1996. Relevance lost and found: critical perspectives on the promise of management accounting. Critical Perspectives on Accounting 7 (5):533 561.

Roslender, R., and S. J. Hart. 2003. In search of strategic management accounting: theoretical and field study perspectives. Management Accounting Research 14 (3):255 279.

Saint Martin, D. 2000. Building the new managerialist state: consultants and the politics of public sector reform in comparative perspective. Oxford; New York: Oxford University Press.

Schelling, T. C. 1960. The Strategy of Conflict. Harvard University Press.

Simons, R. 1995. Levers of Control: How Managers Use Innovative Control Systems to Drive Strategic Renewal. Massachusetts Harvard Business School Press.

Smith, A. 2012 [1776]. Wealth of nations. Ware: Wordsworth.

Von Neumann, J., and O. Morgenstern. 1944. Theory of Games and Economic Behavior. Princeton University Press.

Whittle, A., and F. Mueller. 2010. Strategy, enrolment and accounting: the politics of strategic ideas. Accounting, Auditing \& Accountability Journal 23 (5):626 646.

Wickramasinghe, D., C. Alawattage, and C. Cooper. 2021. Neoliberalism and Management Accounting: reconfiguring governmentality and extending territories $\sim$ Commentary. Accounting, Auditing \& Accountability Journal 34 (3).

Williamson, O. E. 1975. Markets and hierarchies: analysis and antitrust implications a study in the economics of internal organization. New York: Free Press; London: Collier Macmillan.

(1):65 93

1988. The Logic of Economic Organization. Journal of Law, Economics, and Organization 4

1991. Strategizing, economizing, and economic organization. Strategic Management Journal 12 (S2):75 94.

Zwick, D., and N. Dholakia. 2006. Bringing the market to life: Screen aesthetics and the epistemic consumption object. Marketing Theory 6 (1):41 62. 